\title{
Correction to: Inhibition of T cell immunoglobulin and mucin-1 (TIM-1) protects against cerebral ischemia- reperfusion injury
}

Yueying Zheng ${ }^{\dagger}$, Liqing Wang ${ }^{\dagger}$, Manli Chen, Lu Liu, Aijie Pei, Rong Zhang, Shuyuan Gan ${ }^{*}$ and Shengmei Zhu*

\section{Correction to: Cell Commun Signal \\ https://doi.org/10.1186/s12964-019-0417-4}

Following publication of the original article [1], the authors reported that the given name of Liqing Wang was incorrectly published as Liqiang Wang. The original article has been updated.

Published online: 02 September 2019

\section{Reference}

1. Zheng, et al. Inhibition of T cell immunoglobulin and mucin-1 (TIM-1)

protects against cerebral ischemia-reperfusion injury. Cell Commun Signal.

2019;17:103 https://doi.org/10.1186/s12964-019-0417-4.

* Correspondence: phlf9@zju.edu.cn; smzhu20088@zju.edu.cn; smz20088@163.com

${ }^{\dagger}$ Yueying Zheng and Liqing Wang contributed equally to this work. Department of Anesthesiology, The 1st Affiliated Hospital, School of Medicine, Zhejiang University, 79\# Qingchun Road, Hangzhou, Zhejiang Province 310003, People's Republic of China

(c) The Author(s). 2019 Open Access This article is distributed under the terms of the Creative Commons Attribution 4.0 International License (http://creativecommons.org/licenses/by/4.0/), which permits unrestricted use, distribution, and reproduction in any medium, provided you give appropriate credit to the original author(s) and the source, provide a link to the Creative Commons license, and indicate if changes were made. The Creative Commons Public Domain Dedication waiver (http://creativecommons.org/publicdomain/zero/1.0/) applies to the data made available in this article, unless otherwise stated. 